\title{
Kajian Perkembangan Struktur dan Pola Ruang Permukiman Kecamatan Banyumanik
}

\author{
* Rizqy Ridho Prakasa, Tiasa Adimagistra, Wahjoerini \\ Jurusan Perencanaan Wilayah dan Kota, Universitas Semarang \\ *rizqyridho@usm.ac.id, adimagistra.tiasa@usm.ac.id,wahjoerini@usm.ac.id
}

\begin{tabular}{l} 
INFO ARTIKEL \\
\hline Riwayat Artikel: \\
Diterima: $06-08-2020$ \\
Disetujui: $29-08-2020$ \\
\hline
\end{tabular}

Kata Kunci:

Permukiman

Tata Guna Lahan

Daerah Pinggiran

\section{A. LATAR BELAKANG}

Pertumbahan penduduk setiap tahun terjadi di kotakota besar di Indonesia, salah satunya Kota Semarang. Kota Semarang mengalami laju pertumbuhan yang meningkat dari tahun ke tahunnya. Pada tahun 2012 jumlah penduduk Kota Semarang 1.559.168 jiwa, dimana jumlah penduduk di pusat kota yang berada di Kecamatan Semarang Tengah dan Semarang Selatan yakni 154.605 jiwa (RKPD Kota Semarang, 2014). Apabila diasumsikan satu keluarga terdiri dari 5 orang yaitu ayah, ibu, dan anak menghuni dalam satu unit rumah (Soetalaksana, 2000; 8), maka pada tahun 2012

\begin{abstract}
Abstrak: Pertumbuhan penduduk yang tinggi menuntut pemerintah untuk menyediakan kebutuhan akan rumah yang layak huni dan terjangkau bagi seluruh lapisan masyarakat serta dilengkapi fasilitas pelayanan umum. Terbatasnya lahan pada pusat kota membuat perkembangan perumahan bergeser ke daerah pinggiran. Kecamatan Banyumanik salah satu yang direncanakan sebagai daerah yang menampung pertumbuhan penduduk di pusat kota. Tujuan dari penelitian ini ialah mengkaji perkembangan penggunaan lahan permukiman dan struktur ruang Kecamatan Banyumanik. Metode penelitian menggunakan observasi dan overlay peta. Secara keseluruhan dalam kurun waktu 10 tahun, penggunaan lahan permukiman yang berkembang pesat terjadi di tahun 2009 hingga 2019. Dimana pada tahun 2014 luas penggunaan lahan permukiman sebesar $1.659 \mathrm{Ha}$, berkembang di tahun 2019 menjadi $2.138 \mathrm{Ha}$. Perkembangan penggunaan lahan permukiman yang terjadi di tahun 2014 hingga 2019 sebesar $479 \mathrm{Ha}$. Total perkembangan penggunaan lahan permukiman di Kecamatan Banyumanik dari tahun 2009 hingga 2019 dalam kurun waktu 10 tahun, sebesar 919 Ha. Peningkatan harga lahan terjadi di setiap kelurahan yang ada di Kecamatan Banyumanik. Tetapi peningkatan cukup pesat terjadi di Kelurahan Srondol Kulon dan membentuk pola perkembangan linier, Pola perkembangan yang terjadi juga bersifat radial, Selain itu struktur ruang yang terbentuk, menunjukkan model struktur ruang banyak pusat.
\end{abstract}

\begin{abstract}
The high population growth demands the government to provide the need for decent and affordable housing for all levels of society and equipped with public service facilities. Limited land in the city center makes housing development shift to the suburbs. Banyumanik sub-district is one of the areas that is planned to accommodate population growth in the city center. The purpose of this research is to examine the development of residential land use and spatial structure in Banyumanik District. The research method uses field observations and map overlays. Overall, in a period of 10 years, the use of residential land has grown rapidly in 2009 to 2019. Where in 2014 the area of residential land use was 1,659 hectares, growing in 2019 to 2,138 hectares. The development of residential land use that occurred in 2014 to 2019 amounted to 479 hectares. The total development of residential land use in Banyumanik District from 2009 to 2019 in a period of 10 years, amounting to $919 \mathrm{Ha}$. Land price increases occurred in every urban village in Banyumanik District. However, a quite rapid increase occurred in the Kelurahan Srondol Kulon and Ngesrep. The impact of the development of residential land use in the District forms a linear development pattern. The development pattern that occurs is also radial. In addition, the spatial structure formed shows a multi-center spatial structure model.
\end{abstract}

kebutuhan akan rumah di pusat kota sebesar 30.921 unit rumah. Pada kenyataannya rumah di pusat kota yang tersedia dan tergolong gedung permanen berjumlah 23.648 unit rumah, maka penyediaan rumah di pusat kota masih kurang 7.273 unit rumah untuk mengatasi laju pertumbuhan penduduk di Kota Semarang.

Peningkatan kebutuhan sarana permukiman di Kota Semarang selaras dengan makin meningkatknya jumlah penduduk. Permukiman merupakan suatu kebutuhan dasar penting dari manusia yang terus berlanjut dan meningkat seiring dengan pertumbuhan penduduk, dinamika penduduk dan adanya tuntutan ekonomi serta sosial budaya (Pigawati dan Rudiarto, 2011). Menurut 
pasal 5 ayat (1) UU No 4 Tahun 1992 tentang perumahan dan permukiman setiap warga negara mempunyai hak untuk menempati, menikmati, dan memiliki rumah yang layak dalam lingkungan yang sehat, aman, serasi, teratur. Kimtaru (2004) menyebutkan bahwa kebutuhan akan permukiman dibagi menjadi dua hal pokok ialah berdasarkan trend pertumbuhan penduduk secara alamiah dan berdasarkan rumah yang layak huni. Pemilihan lokasi permukiman juga menjadi kebutuhan akan permukiman. Pemilihan lokasi permukiman merupakan salah satu faktor yang dapat perhatian lebih, karena lokasi permukiman ini mempengaruhi harga lahan. Semakin mudah aksesbilitas suatu lokasi, maka semakin tinggi harga lahan. Harga lahan yang tinggi biasanya terjadi di pusat-pusat kota seperti halnya pusat Kota Semarang. Fenomena ini membuat pembangunan permukiman bergeser kearah pinggiran yang harga lahannya relatif murah.

Perkembangan penggunaan lahan permukiman Kecamatan Banyumanik, yang merupakan daerah pinggiran Kota Semarang, dapat menimbulkan permasalahan yang kompleks. Permasalahan yang muncul meliputi dampak penataan guna lahan, dampak sosial masyarakat, dan kantong-kantong perumahan yang tidak tertata rapi di daerah pinggiran kota. Perkembangan penggunaan lahan permukiman merupakan tanggung jawab baik pemerintah, pihak swasta, dan masyarakat. Karena pemerintah hanya mengatur kebijakan tata guna lahan saja, namun untuk pembangunan permukiman sendiri dikembangkan oleh masyarakat dan pihak swasta. Kedua belah pihak ini yang memiliki peran penting dalam membentuk pola permukiman yang ada di daerah pinggiran.

\section{B. METODE PENELITIAN}

\section{Tahapan Penelitian}

Tahapan penelitian merupakan tahapan menentukan data apa saja yang dibutuhkan hingga survei pendahuluan untuk mengetahui kondisi langsung di lapangan. Kegiatan- kegiatan yang termasuk dalam tahap persiapan adalah sebagai berikut:

1. Penentuan dasar penelitian yang disusun dalam latar belakang, justifikasi pemilihan wilayah tersebut, substansi apa saja yang akan dibahas, perumusan kerangka pikir yang akan digunakan sebagai alur penelitian hingga batasan penelitian terhadap penelitian yang telah dilakukan sebelumnya;

2. Pengkajian literatur - literatur yang terkait dengan substansi penelitian yakni mengenai kebijakan serta karakteristik baik permukiman dan masyarakat yang bertempat tinggal di Kecamatan Banyumanik. Sehingga ditemukan variabel penelitian yang akan dikaji;

3. Melakukan survei pendahuluan dan pengamatan terhadap wilayah studi serta instansi yang berkaitan. Survei pendahuluan dilakukan agar memahami lokasi penelitian dan mengetahui objek secara garis besar. Keuntungan melakukan survey pendahuluan adalah dapat memverifikasi apakah penelitian dapat dilakukan pada wilayah dan waktu tersebut;

4. Menyusun form observasi dan kebutuhan data.

\section{Tahapan Analisis Perkembangan Penggunaan Lahan Permukiman}

Analisis spasial ini menggunakan pengelolaan citra satelit dengan metode penginderaan jauh. Dimana dengan analisis ini dapat melihat perkembangan penggunaan lahan permukiman tahun 2008, 2013, dan 2018 dengan citra satelit. Selain itu, dapat mengetahui kondisi eksisting dan pola permukiman yang tersebar di Kecamatan Banyumanik. Terdapat 2 metode dalam penggunaan analisis spasial ini :

\section{a. Analisis Overlay Peta}

Dalam sistem informasi geografis dikenal teknik overlay, yaitu teknik overlay logika dan teknik overlay aritmatika. Overlay logika adalah metode untuk mendapatkan peta melalui klasifikasi irisan antara dua layer informasi. Ada 4 jenis yang termasuk overlay ini, yaitu: impose, stamp, joint dan matrix. Untuk mendapatkan peta yang didasarkan pada analisis komparatif dua layer peta. Metode ini didasarkan pada suatu matrix dimana layer peta 1 menyatakan baris dan layer peta 2 menyatakan kolom. Klasifikasi peta baru merupakan hasil perpotongan layer-layer peta ini berdasarkan matrix. Untuk mendapatkan peta baru berdasarkan operasi aritmatika (tambah, kurang dan pembagian) pada nilai atribut. Overlay ini digunakan bilamana pembobotan merupakan hal yang dipentingkan dalam analisisnya. Analisis pola perkembangan penggunaan lahan permukiman Kecamatan Banyumanik khususnya secara fisik dapat diketahui melalui peta citra satelit dari periode tahun ke tahun. Penggabungan peta dari tahun ke tahun dan di overlay-kan maka akan diketahui lahan mana saja yang mengalami perubahan bentuk dari lahan kosong ke lahan terbangun, selain itu mengetahui pola-pola yang terbentuk. Tidak hanya Kecamatan Banyumanik, kawasan sekitarnyapun diturut sertakan agar dapat diketahui dampak dari perkembangan lahan disekitar Kecamatan Banyumanik.

\section{b. Analisis Pola dan Struktur Ruang}

Analisis ini digunakan untuk mengetahui pola penggunaan lahan permukiman di Kecamatan Banyumanik dan bentuk perkembangannya (konsentris, linier, dan meloncat).

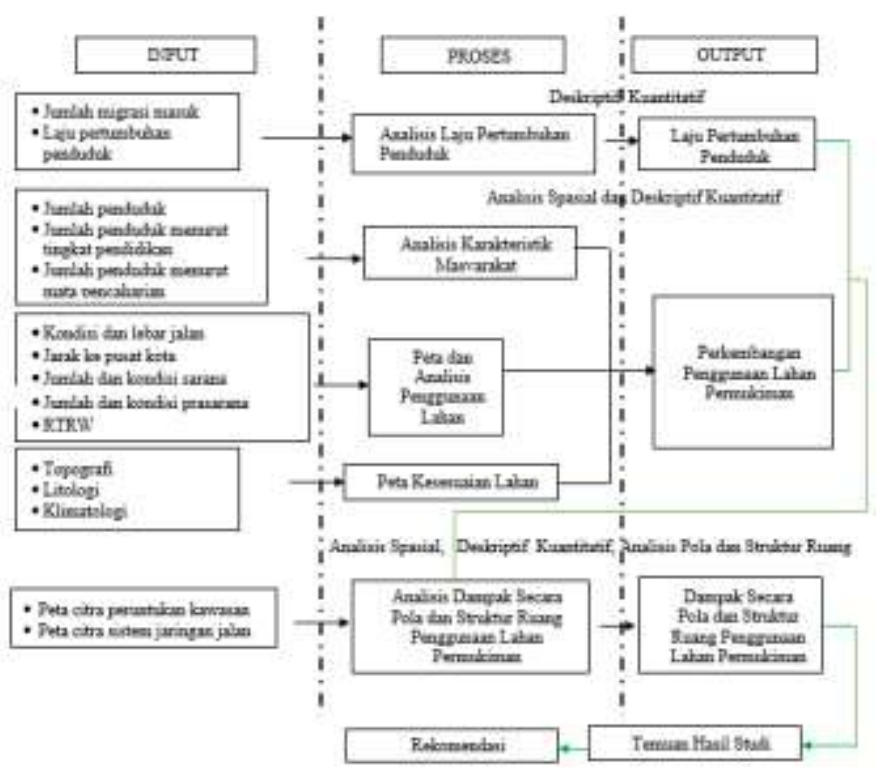

Gambar 1. Kerangka Analisis 


\section{HASIL DAN PEMBAHASAN}

\section{Analisis Laju Perkembangan Penggunaan Lahan Permukiman di Kecamatan Banyumanik}

Pada tahun 2009 hingga tahun 2014 penggunaan lahan permukiman mengalami perkembangan penggunaan lahan permukiman sebesar 440 Ha. Sedangkan di tahun 2019 mengalami perkembangan dalam penggunaan lahan permukiman sebesar $479 \mathrm{Ha}$ dari tahun 2014. Dalam kurun waktu 11 tahun, Kecamatan Banyumanik mengalami perkembangan penggunaan lahan permukiman sebesar 919 Ha. Perkembangan yang terjadi pada tahun 2009, 2014, hingga 2019 dialami oleh seluruh kelurahan yang ada di Kecamatan Banyumanik.

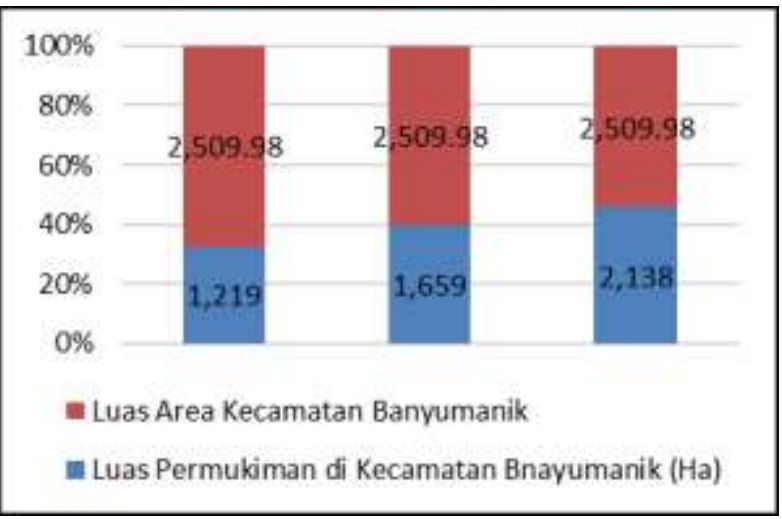

Gambar 2. Grafik Penggunaan Lahan Permukiman Kecamatan Banumanik

Pada tahun 2009 hanya Kelurahan Srondol Wetan dan Kelurahan Sumurboto yang terlihat cukup padat akan penggunaan lahan permukimannya. Kedua kelurahan cukup padat, karena letaknya yang strategis, dekat dengan Kampus Universitas Diponegoro. Pada tahun 2014 perkembangan penggunaan lahan permukiman menuju ke arah Kelurahan Pudakpayug dan Kelurahan Gedawang. Perkembangan ini terjadi karena mengikuti perkembangan infrastruktur jalan. Selain itu, kedua kelurahan tersebut masih terdapat lahan non terbangun dengan kondisi kelerengan yang datar.

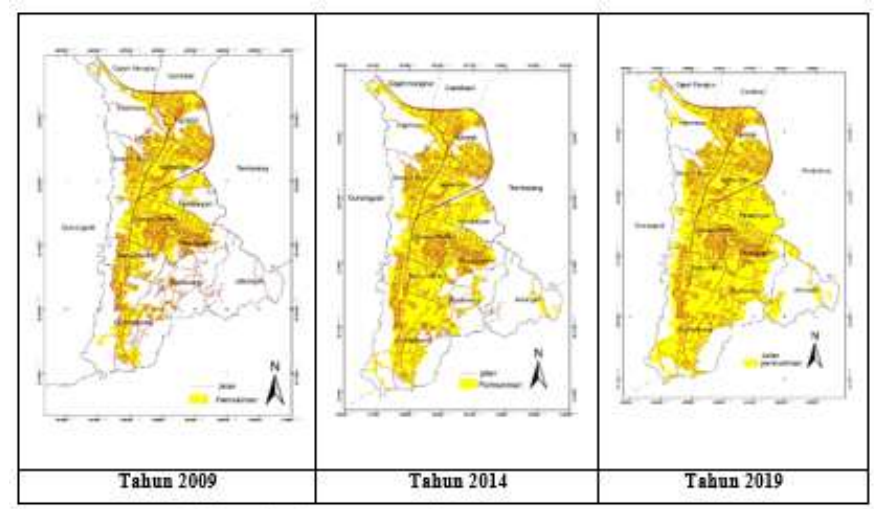

Gambar 3. Laju Penggunaan Lahan Permukiman Kecamatan Banumanik Tahun 2009, 2014, dan 2019

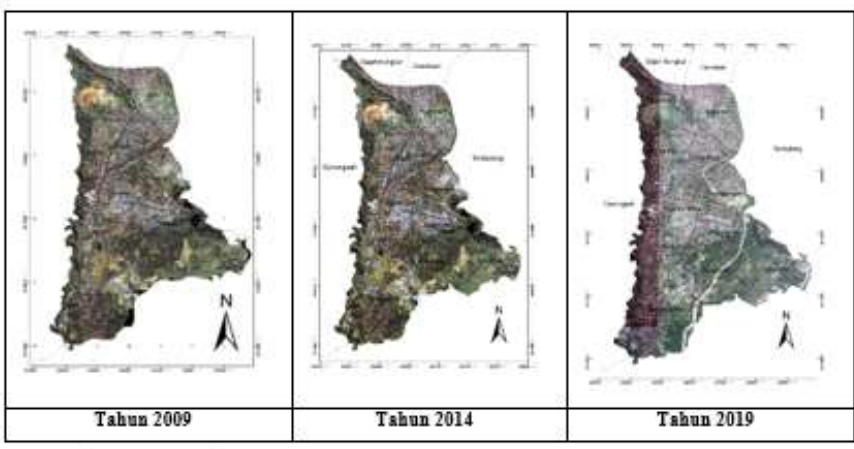

Gambar 4. Peta Satelit Citra Ikonos Kecamatan Banumanik Tahun 2009, 2014, dan 2019

\section{Analisis Karakteristik Harga Lahan di Kecamatan Banyumanik}

Apabila dilihat dari karakteristik harga lahan, Kecamatan Banyumanik (daerah pinggiran) lebih murah dibandingkan dengan harga lahan yang ada di Kawasan Simpang 5 (daerah pusat kota). Kecamatan Banyumanik berada di Kota Semarang bagian atas, sehingga tidak akan terkena bencana banjir. Selain itu, terdapat beberapa lahan yang kosong dan kawasan yang masih tampak asri. Hal ini, membuat Kecamatan Banyumanik nyaman untuk ditinggali. Beberapa kawasan di Kecamatan Banyumanik yang memiliki harga lahan, biasanya jauh dari jalan utama atau pusat Kecamatan Banyumanik. Sehingga kawasan tersebut, lebih besar kemungkinannya terjadi perubahan fungsi lahan.

Tabel 1

Nilai Jual Objek Pajak (NJOP) Kecamatan Banyumani Tahun 2009, 2014, dan 2019

\begin{tabular}{|c|l|r|r|r|}
\hline \multirow{2}{*}{ No } & \multirow{2}{*}{ Kelurahan } & \multicolumn{3}{|c|}{ NJOP (Rp/ m $\mathbf{~})$} \\
\cline { 3 - 5 } & & $\mathbf{2 0 0 9}$ & $\mathbf{2 0 1 4}$ & \multicolumn{1}{|c|}{$\mathbf{2 0 1 9}$} \\
\hline 1 & Pudakpayung & 1.274 .000 & 1.573 .000 & 2.352 .000 \\
\hline 2 & Gedawang & 464.000 & 614.000 & 916.000 \\
\hline 3 & Jabungan & 394.000 & 394.000 & 537.000 \\
\hline 4 & Pedalangan & 1.147 .000 & 1.416 .000 & 1.416 .000 \\
\hline 5 & Banyumanik & 1.274 .000 & 1.573 .000 & 2.352 .000 \\
\hline 6 & Srondol & 1.862 .000 & 2.176 .000 & 3.100 .000 \\
& Kulon & & & \\
\hline 7 & Srondol & 1.772 .000 & 2.013 .000 & 2.176 .000 \\
\hline 8 & Wetan & & & \\
\hline 9 & Tinjomoyo & 2.176 .000 & 2.508 .000 & 3.745 .000 \\
\hline 10 & Padangsari & 1.176 .000 & 2.176 .000 & 3.100 .000 \\
\hline 11 & Sumurboto & 1.862 .000 & 1.274 .000 & 1.274 .000 \\
\hline
\end{tabular}

Sumber: PBB Kota Semarang Tahun 2009, 2014, dan 2019

Tabel diatas menunjukkan bahwa karakteristik harga lahan Kecamatan Banyumanik semakin naik tiap tahunnya. Kenaikan ini terjadi di seluruh kelurahan yang ada di Kecamatan Banyumanik. Harga tertinggi yang terjadi di tahun 2014-2019 pada Kelurahan Ngesrep yakni berkisar Rp 2.000.000,00 - Rp 3.800.000,00 per $\mathrm{m}^{2}$. Hal ini membuktikan bahwa daerah pinggiran Kota Semarang sangat berkembang, nila harga lahan yang bisa dikatakan tinggi. Harga lahan ini ditentukan dengan aksesbilitas menuju pusat kota serta fungsi dari kawasan tersebut. Kelurahan Ngesrep memiliki harga lahan yang paling tinggi, dikarenakan aksesbilitas menuju pusat kota dekat dan mudah. Selain itu, letaknya yang dekat 
dengan Universitas Diponegoro membuat harga lahan semakin tinggi.

Kelurahan Jabungan dan Kelurahan Gedawang memiliki harga yang paling rendah, bila dibandingkan dengan kelurahan-kelurahan yang ada di Kecamatan Banyumanik. Harga lahan Kelurahan Jabungan berkisar Rp 300.000,00 sampai Rp 5.550.000,00 per m2. Sedangkan Kelurahan Gedawang memiliki harga lahan $\mathrm{Rp}$ 400.000,00 hingga Rp 1.000.000 per m2. Harga lahan didua kelurahan tersebut dipengaruhi dengan jarak menuju pusat kota yang cukup jauh, serta susah dijangkau untuk transportasi umum. Selain itu, harga lahan yang cukup murah di kedua kelurahan tersebut, karena luas lahan non terbangunnya lebih luas jika dibandingkan dengan lahan terbangunnya

\section{Analisis Dampak Perkembangan Penggunaan Lahan Permukiman Secara Pola dan Struktur Ruang di Kecamatan Banyumanik}

Analisis dampak perkembangan penggunaan lahan permukiman dapat mengetahui struktur dan pola yang terbentuk di Kecamatan Banyumanik, selain itu mengetahui pola yang terjadi di perumahan dan perkampungan yang terjadi di koridor jalan kolektor dan koridor jalan lingkungan.

Stuktur ruang Kecamatan Banyumanik mengikuti teori sektor. Dimana Kecamatan Banyumanik memiliki beberapa kawasan, meliputi: kawasan permukiman, kawasan perdagangan dan jasa, kawasan pendidikan, kawasan pemerintahan, sera kawasan permukiman. Kawasan perdagangan dan jasa terletak di pinggirpinggir jalan besar, seperti jalan arteri dan jalan kolektor. Kawasan permukiman letaknya di belakang kawasan perdagangan dan jasa. Dimana dalam kawasan permukiman terdapat fasilitas-fasilitas pendukung seperti pendidikan dan kesehatan. Pemicu perkembangan kawasan permukiman, dengan dibangunnya PERUMNAS Banyumanik dan Perumahan SBI. PERUMNAS Banyumanik ini diperuntukkan bagi masyarakat golongan menengah ke bawah, sedangkan Perumahan SBI diperuntukkan bagi masyarakat golongan menengah keatas.

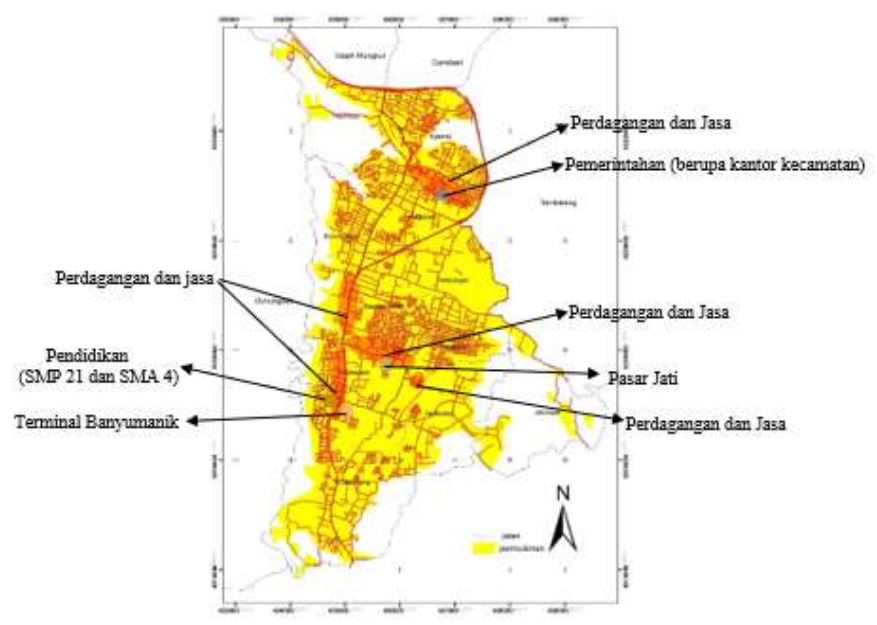

Gambar 5. Peta Struktur Ruang Kecamatan Banyumanik

Pola perkembangan yang terjadi pada tahun 2009, 2014 hingga 2019 tidak berubah yakni pola perkembangan secara linier. Dimana perkembangan yang terjadi mengikuti oleh perkembangan aksesbilitas atau jalan, berupa jalan arteri, jalan kolektor, dan jalan lingkungan. Pola perkembangan yang terjadi juga bersifat radial, dimana sifat ini tidak terus menerus sama dengan awal perkembangannya memusat dalam satu wilayah, melainkan ditahun selanjutnya perkembangannya bersifat tidak merata. Selain itu struktur ruang yang terbentuk, menunjukkan model struktur ruang banyak pusat. Dimana pusat-pusat tersebut membentuk 2 zona yakni daerah pusat kegiatan dan zona tempat tinggal daerah pinggiran.

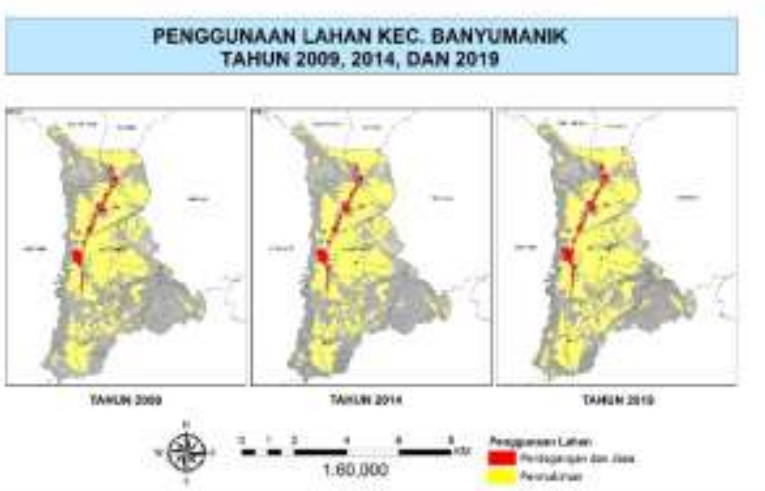

Gambar 6. Peta Pola Ruang Kecamatan Banyumanik Tahun 2009, 2014, dan 2019

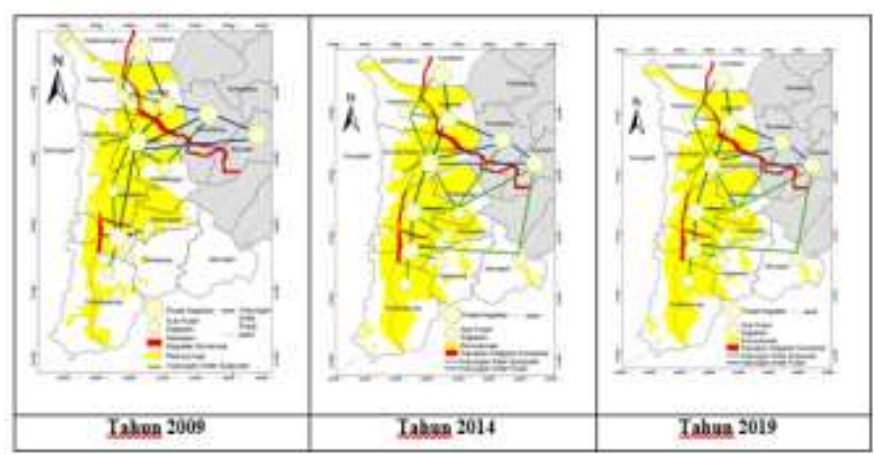

Gambar 7. Peta Pola Struktur Ruang Kecamatan Banyumanik Tahun 2009, 2014, dan 2019

\section{SIMPULAN DAN SARAN}

Berdasarkan hasil analisis yang telah dilakukan untuk mengetahui perkembangan penggunaan lahan permukiman yang terjadi di Kecamatan Banyumanik, sebagai daerah pinggiran Kota Semarang. Mengetahui dampak secara pola dan struktur ruang yang terjadi, akibat perkembangan penggunaan lahan permukiman di Kecamatan Banyumanik. Maka dari itu, temuan dari penelitian perkembangan penggunaan lahan permukiman di daerah pinggiran dengan wilayah studi Kecamatan Banyumanik, sebagai berikut :

1. Berdasarkan tujuan penelitian yaitu mengkaji perkembangan penggunaan lahan permukiman di Kecamatan Banyumanik pada tahun 2009, 2014, dan 2019, sehingga dapat dilihat penggunaan lahan permukiman di Kecamatan Banyumanik mengalami perkembangan di tahun 2009, 2014, dan 2019. Perkembangan penggunaan lahan permukiman terjadi di seluruh kelurahan yang ada di Kecamatan Banyumanik. Kelurahan yang mengalami 
perkembangan penggunaan lahan permukiman cukup pesat yakni Kelurahan Pudakpayung. Dalam kurun waktu 10 tahun (2009-2019) Kelurahan Pudakpayung mengalami perkembangan penggunaan lahan permukiman sebesar $316 \mathrm{Ha}$. Secara keseluruhan dalam kurun waktu 10 tahun, penggunaan lahan permukiman yang berkembang pesat terjadi di tahun 2009 hingga 2019. Dimana pada tahun 2014 luas penggunaan lahan permukiman sebesar $1.659 \mathrm{Ha}$, berkembang di tahun 2019 menjadi 2.138 Ha. Perkembangan penggunaan lahan permukiman yang terjadi di tahun 2014 hingga 2019 sebesar 479 Ha. Total perkembangan penggunaan lahan permukiman di Kecamatan Banyumanik dari tahun 2009 hingga 2019 dalam kurun waktu 10 tahun, sebesar 919 Ha.

2. Hasil analisis karakteristik lahan di Kecamatan Banyumanik dengan pendekatan melihat Nilai Jual Objek Pajak (NJOP), ditemukan bahwa perkembangan penggunaan lahan permukiman mempengaruhi harga lahan yang semakin meningkat. Peningkatan harga lahan terjadi di setiap kelurahan yang ada di Kecamatan Banyumanik. Tetapi peningkatan cukup pesat terjadi di Kelurahan Srondol Kulon dan Ngesrep. Kedua kelurahan ini sama-sama memiliki wilayah pusat komersial cukup luas, jika dibandingkan dengan kelurahan yang ada di Kecamatan Banyumanik. Selain itu, kedua kelurahan ini memiliki jarak yang cukup dekat menuju pusat Kota Semarang, serta memiliki kemudahan dalam hal aksesbilitas.

3. Dampak perkembangan penggunaan lahan permukiman di Kecamatan membentuk pola perkembangan linier. Dimana perkembangan yang terjadi mengikuti oleh perkembangan aksesbilitas atau jalan, berupa jalan arteri, jalan kolektor, dan jalan lingkungan. Pola perkembangan yang terjadi juga bersifat radial, dimana sifat ini tidak terus menerus sama dengan awal perkembangannya memusat dalam satu wilayah, melainkan ditahun selanjutnya perkembangannya bersifat tidak merata. Selain itu struktur ruang yang terbentuk, menunjukkan model struktur ruang banyak pusat.

\section{DAFTAR RUJUKAN}

[1]

Affan, Faisal Musaqqif. 2014. "Analisis Perubahan Penggunaan Lahan Untuk Permukiman dan Industri dengan Menggunakan Sistem Informasi Geografis (SIG)" dalam Jurnal Ilmiah Pendidikan Geografi Vol. 2/ No. 1 Oktober 2014. Semarang. IKIP Veteran Semarang.

[2]

Irwan, Zoera'ini Djamal. 2004. Tantangan Lingkungan dan Lansekap Hutan Kota. Universitas Michigan : Cides.

[3] Kabupung, Sonny Fernando. 2012. "Studi Citra Kota Maumere di Nusa Tenggara Timur", Tesis S-2 Program Studi Magister Teknik Arsitektur Universitas Atmajaya Yogyakarta.

[4] Kurniawati, Feri Ema. 2010. "Perkembangan Struktur Ruang Kota Semarang Periode 1960-2007 (Studi Pengembangan Struktur Ruang dari Masa Pasca Kolonial Sampai 2007)", Skripsi S-1 Fakultas Geografi Universitas Muhammadiyah Surakarta. Pigawari, Bitta dan Iwan Rudiarto. 2011. " Penggunaan Citra Satelit untuk Kajian Perkembangan Kawasan Permukiman di kota Semarang", dalam Jurnal Forum Geografi
Universitas Muhammadiyah Surakarta Vol.25/ No.2. Surakarta. Universitas Muhammadiyah Surakarta, [5] Fakultas Geeografi.

Pontoh, Nia Kurniasih dan Dede J. Sudrajat. 2005. "Hubungan Perubahan Penggunaan Lahan dengan Limpasan Air Permukaan : Studi Kasus Kota Bogor", dalam jurnal Perencanaan Wilayah dan Kota Vol. 16/ No. 3. Bandung. Program Magister Perencanaan Wilayah dan Kota Instittu 6] Teknologi Bandung.

"Aspek Pembiayaan Peruma dalam majalah usahawan. No O3 Tahun XXIX. Maret. hlm 8.

[7]

[8] Penelitian Bisnis. Bandung : Penerbit CV. Alfabeta.

Tallo, Amandus Jong dkk. 2014. "Identifikasi Pola Morfologi Kota (Studi Kasus : Sebagian Kecamatan Klojen, di Kota Malan)", dalam jurnal Perencanaan Wilayah dan Kota Vol. 25/ No. 3. Bandung. SAPPK Institut Teknologi Bandung.

[9] Theresiana, Ester dan Santy Paulla Dewi. 2013. "Analisis Perkembangan Struktur Ruang Kawasan Bersejarah Kampung Kauman Kota Semarang", dalam Jurnal Teknik PWK Vol. 2/ No.3. Semarang. Jurusan Teknik Perencanaan Wilayah Kota Fakultas Teknik Universitas Diponegoro Semarang.

[10] tentang Perumahan dan Permukiman. UU No 4 tahun 1992

[11] Widyastomo, Deasy. 2011. "Perubahan Pola Permukiman Tradisional Suku Sentani di Pesisir Danau Sentani”, dalam Jurnal Permukiman Vol. 6/ No. 2 Agustus 2011. Bandung. Pusat Litbang Permukiman, Badan Litbang Kementrian Pekerjaan Umum. 